\title{
Profile of cochlear implant users of the city of Manaus
}

\author{
Mariana dos Santos Pedrett', Sandra Costa Moreira². \\ 1) Specialist. Masters degree student in Language Studies at the Federal University of Amazonas - UFAM. Bolsita Foundation for Research Support of the Amazon-FAPEAM. \\ - (Phonoaudiologist Center of Manaus City Department of Education. Professor of Phonoaudiology University Center North.). \\ 2) Specialist. - (In Time Phonoaudiologist TV. Professor at the University Center North. \\ Institution: Centro Universitário do Norte - UNINORTE \\ Manaus / AM - Brazil. \\ Mailing address: Mariana dos Santos Pedrett - Rua Dez de Julho, 873 - Center - Manaus / AM - Brazil - Zip code: 69010-060 - Telephone: (+55 92) 3671-8046 - \\ E-mail: mariana.pedrett@hotmail.com \\ Article received in March 23, 2012. Article approved in June 7, 2012.
}

\section{SUMMARY}

Introduction: The cochlear implant is a device that is intended to substitute for the function of cochlear hair cells, electrically stimulate auditory nerve fibers, and contribute to the perception of speech sounds. However, the surgical procedure alone is not enough for the user to achieve favorable results in habilitation/rehabilitation.

Objective: To characterize the patients from Manaus who have received cochlear implants based on the criteria for surgery. Methods: We conducted a retrospective cross-sectional study of 15 cases and recorded etiological aspects of deafness, age, gender, duration of implant use, use of hearing aids, and participation in individual therapy. Data were recorded in a protocol designed specifically for this purpose. All patients were natives of Manaus.

Results: The leading etiological aspect was ototoxicity associated with prematurity in newborns undergoing treatment in the neonatal intensive care unit. The age at surgery is carefully observed in the evaluation of implant centers, as well as if the candidate is pre-or post-lingual. In this study, $73 \%$ of patients were pre-lingual and did not benefit from hearing aids. As to the degree and type of hearing loss, 93\% had audiological reports indicating profound bilateral sensorineural hearing loss and 7\% had severe bilateral sensorineural hearing loss. This latter finding confirmed one of the basic principles of implant placement. Conclusion: This study allowed us to verify that there are reduced number of cochlear implant recipients in Manaus, but they have met the criteria required by implant centers located in other states of Brazil.

Keywords: cochlear implants; deafness; population characteristics.

\section{INTRODUCTION}

The cochlear implant is a device that tries to replace the function of cochlear hair cells and electrically stimulates the auditory nerve fibers, creates the sensation of hearing in children with hearing loss, and allows the perception of speech sounds to occur more easily. However, surgery alone is not enough for users to achieve favorable results in habilitation/rehabilitation. Patients selected to receive the implant must meet a number of criteria, including severe or profound bilateral sensorineural hearing loss and trial of conventional hearing aids with no benefit.

The SUS (Unified Health System) does not provide this service in Manaus, which is why candidates migrate to implant centers in other states for the surgery.
However, one of the specific requirements of these centers is the availability of specialized therapeutic services in the city of origin, without which the surgery is not feasible. A large majority of these patients, if SUS performs the implantcannot afford to make up a team of rehabilitation specialists. The primary objective of this study was to characterize the profile of recipients of cochlear implant devices in Manaus, analyzing the medical records and protocols of the Association of Support for Hearing and Cochlear Implant Users of the Amazon (AMADA) with regard to the patients who received implants at implant centers and other points. AMADA is an institution that provides support to people who need to use this technology, so a customer is not characterized. We considered etiological aspects of deafness, age, sex, proportion of patients pre-and post-lingual, previous use of a hearing aid, time of use of the implant, and also consistent follow-up with specialized speech therapists. 


\section{Cochlear Implant}

Thanks to changes in public health policy on hearing, there has been an increase in the number of facilities for cochlear implant surgery in Brazil, especially after the creation of ordinances of October 20, 1999, marking the surgical procedure as a treatment option for hearing and an ordinance from 2004 that defined the National Policy of Hearing Health Care and provided the grounds for basic-, medium-, and high-complexity care. These specifics maintain and justify the character of this research in an attempt to characterize the study population and allow the reflection of the inclusion of this service in the city of Manaus.

For Pinto (2007, p.43) the evolution of language in these children does not always occur as expected and is influenced by a number of factors such as age, degree of hearing loss, language skills pre-implantation, etiology of hearing loss, and therapeutic approach among others.

\section{Ototoxicity}

Acquired hearing loss by ototoxic substances can occur at any age, but in this work, we refer to those substances that affect newborns who need to stay in the Neonatal Intensive Care Unit (NICU). According to Russo and Santos (1989, p.73), these are "high-risk infants who fall under some conditions, such as family history of hearing loss, $[. .$.$] weight babies at birth less than$ 1500g."

Also in Russo and Santos (1989, p. 44) is that "the ingestion of drugs considered ototoxic, by a woman during pregnancy, can cause hearing loss in infants it has generated."

As per Jornada (2009, p. 27) "ototoxic drugs can affect the system cochlear or vestibular system, or both, changing two important functions in the body: hearing and balance." The degree of hearing impairment is subject to variations and depends on the gestational period in which the drug was used, i.e., if it occurred in the first trimester or between the seventh and eighth weeks, the effects to the embryo are devastating.

\section{Meningitis}

As per Porto (2002, p. 89) "meningitis presents high prevalence in Brazil and worldwide, constituting one of the most important causes of profound hearing loss." Another author reinforces the fact:
The main etiology of hearing loss in childhood are the genetic cause (non-syndromic or syndromic) congenital infections (eg, rubella, cytomegalovirus, toxoplasmosis), perinatal causes and infections acquired (eg sequelae of meningitis) [...] among the infectious diseases which is hearing the sequel, the most serious is meningitis. (Ramalho, 2008, p. 01).

\section{Rubella}

Research in Manaus point of rubella cases reported with suspected pregnancy and risk of silent congenital rubella syndrome. As Mota (2004, p.43) of the 3.818 reported cases were recorded in the field of research sheet 103 cases of suspected pregnancy or 3\%. The possibility of underreporting of the disease, these records probably represent a small portion of reality, but is not always essential to the total number of disease to establish the system of prevention and control measures, since for these 103 cases, 83 (80.6\%) conducted tests and confirmed 42 (50.6\%) and discarded 41 (49.4\%).

To Russo and Santos (1989, p. 45) "maternal rubella syndrome can present a variety of defects with various degrees of severity. [...]" Presents an auditory manifestation of the disease in $50 \%$ of cases."

\section{Aspects Relevant To Use Cochlear Implants}

\section{Pre-lingual deafness and post-lingual}

According to Kozlowski (2000, p. 42) "pre-lingual deafness occurs in individuals who have acquired hearing loss before the development of language. In cases of post-lingual deafness, we classify all those individuals who lost their hearing after the development of language." It is important to identify such features to track goals in caring for patients using the device. According to Moret (2005, p. 78), for children with hearing impairment prelingual deployment depends on information provided by the cochlear implant to acquire oral language.

\section{Age and duration of auditory deprivation}

Research by Leal (2010, p. 189) showed that "patients aged 0-3 years are patients pre-and peri-lingual with greater potential benefit to the CI." According to Sant'Anna (2008, p. 58) "For children with pre-lingual hearing loss, surgery should preferably be made up to 6 years of age and the prognosis is better for those implanted until 4 years. Children over 6 years will have more limited prognosis." 
Type and degree of hearing loss

Thus, several studies have been conducted regarding the criteria for cochlear implant use. For Porto (2002, p. 14) "in cases of profound sensorineural hearing loss, the implant is indicated as a treatment method recognized worldwide as an effective aid in the rehabilitation of hearing sequel."

Criteria for selection and rejection of patients for the cochlear implant is constantly changing as the research proceeds. Any patient with severe hearing loss and / or deep it will not benefit from the use of hearing aids and has no medical or psychological contraindications for use of the device can be a potential candidate for the CI (LEAL, 2010, p.189).

Use of a hearing aid

For Sant'Anna (2008, p.58) "children 1 to 17 years with bilateral sensorineural hearing loss severe to profound, provided they have hearing aids and speech therapy done systematically for at least 6 months and show no trend of listening skills."

\section{METHOD}

This is a quantitative, cross-sectional study approved on 08/06/2010 by the Ethics and Research Center University of CEP-North (Protocol 243/10)

\section{Casuistry}

The data were collected from medical records of patients with cochlear implant of AMADA (Association of Amazonian Support for Hearing and Cochlear Implant Users) according to the consent of the responsible institution. The AMADA is located in the Joint Atilio Andreazza, Acari Street, block E, n. 50, Japiim. It is an association that supports patients undergoing cochlear implant surgery by SUS sent to implant centers located in other states, since the procedure takes place in Manaus only by agreement.

The inclusion criteria used in this study were: medical records of patients treated with cochlear implant in the institution, native of the city of Manaus, randomly selected, not to exceed a total of 15 .

Exclusion criteria were: medical records of patients without cochlear implant, not born in the city of Manaus, and exceeding the total of 15 randomly selected records.

\section{Material}

After signing an informed consent for the presidency for the authorization of the survey, data were collected through review of 15 randomly selected medical records of patients using the device. The data were recorded in the protocol developed specifically for this purpose. Data were analyzed for the most common etiology of deafness, number of patients with cochlear implant pre-lingual versus post-lingual, age and gender of the informants, the degree and type of hearing loss, duration of use of the device and participation in therapy with a speech therapist. After data collection was carried out, data analysis was performed including computation and aggregation of data and subsequent statistical analysis of the descriptive data, with the results organized in tables and graphs.

\section{RESULTS}

\section{Characterization of the population}

We analyzed medical records of 15 patients of AMADA. Of the 15 randomly selected, 53.3\% $(n=8)$ patients were male and $46.6 \%(n=7)$ were female. The minimum age was 3 years, the maximum was 71 years. The largest population was aged 4-6 years, as can be seen in Table 1.

Otological history: Use of hearing aids for prelingual patients

Image 1 shows that $55 \%(n=6)$ used hearing aids 2 to 3 years prior to implant surgery, $36 \%(n=4) 0$ of 1 year, and $9 \%(n=1)$ did not respond.

Characteristics of the subjects second language acquisition

$73 \%(n=11)$ of patients were pre-lingual, and $27 \%$ $(\mathrm{n}=4)$ post-lingual (Image 2$)$.

Table I . Distribution of patients according to age and gender.

\begin{tabular}{lcccccc}
\hline Age group & \multicolumn{2}{c}{ Male } & \multicolumn{2}{c}{ Female } & \multicolumn{2}{c}{ Total } \\
& $N$ & $\%$ & $N$ & $\%$ & $N$ & $\%$ \\
\hline I-3 years & 00 & $0 \%$ & 0 I & $6.6 \%$ & 01 & $6.6 \%$ \\
4-6 years & 04 & $26.8 \%$ & 02 & $13.4 \%$ & 06 & $40.2 \%$ \\
7-9 years & 03 & $20 \%$ & 01 & $6.6 \%$ & 04 & $26.6 \%$ \\
I0-13 years & 00 & $0 \%$ & 0 I & $6.6 \%$ & 0 I & $6.6 \%$ \\
Above I 8 years & 01 & $6.6 \%$ & 02 & $13.4 \%$ & 03 & $20 \%$ \\
\hline Total & 08 & $53.4 \%$ & 07 & $46.6 \%$ & 15 & $100 \%$ \\
\hline
\end{tabular}




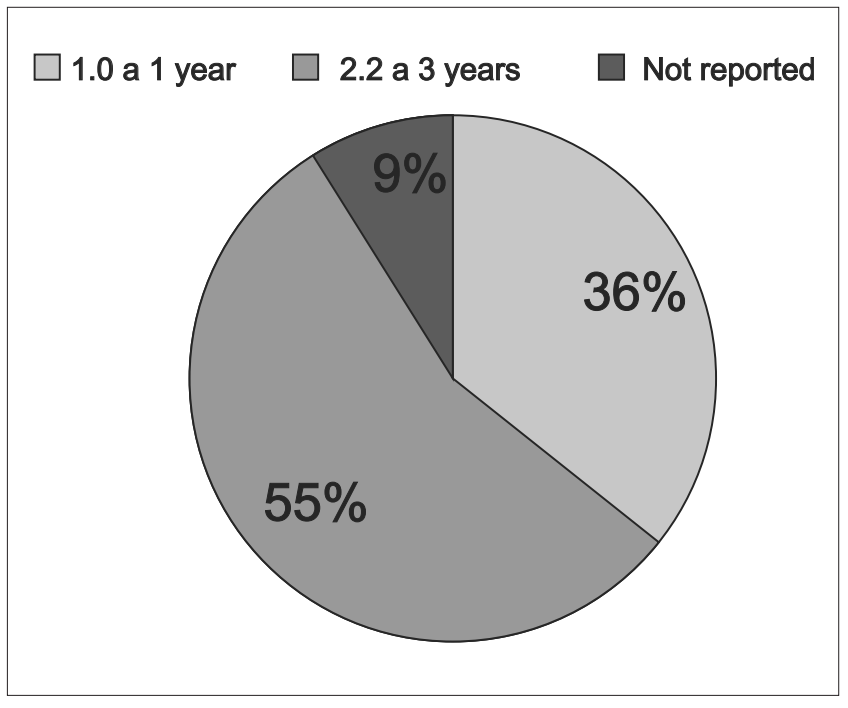

Image 1. Time of use of hearing aid

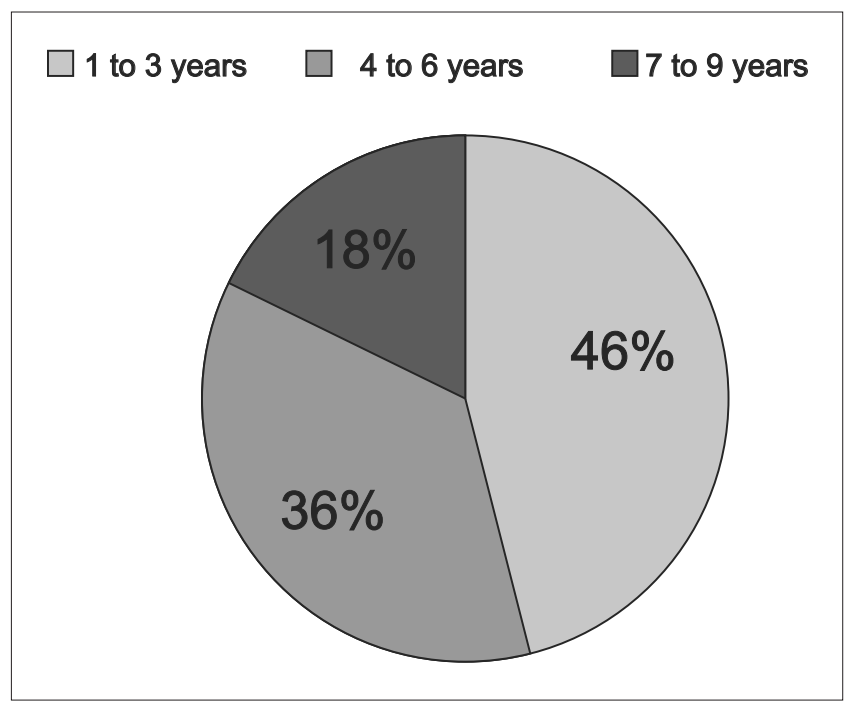

Image 3. Age of pre-lingual patients at the time of surgery.

Age factor in pre-lingual patients at the time of surgery

In Image 3 we see that $46 \%(n=05)$ were prelingual patients who underwent surgery between 1 and 3 years, 36\% $(n=04)$ between 4 and 6 years, and 18\% $(n=$ 02) between 7 and 9 years.

\section{Age factor in post-lingual patients at surgery}

Of the patients surveyed, $75 \%(n=03)$ underwent cochlear implant over the age of 18 years, and 25\% $(n=01)$ from 07 to 9 years (Image 4).

\section{Speech and Hearing Pathology}

We found that $80 \%(n=12)$ of patients participated

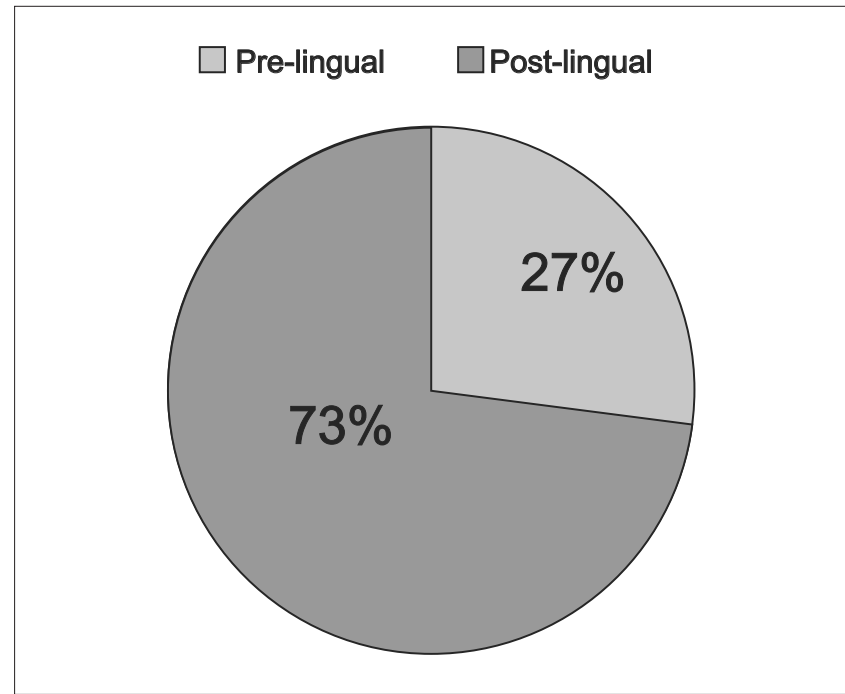

Image 2. Characterization of pateints' second language acquisition.

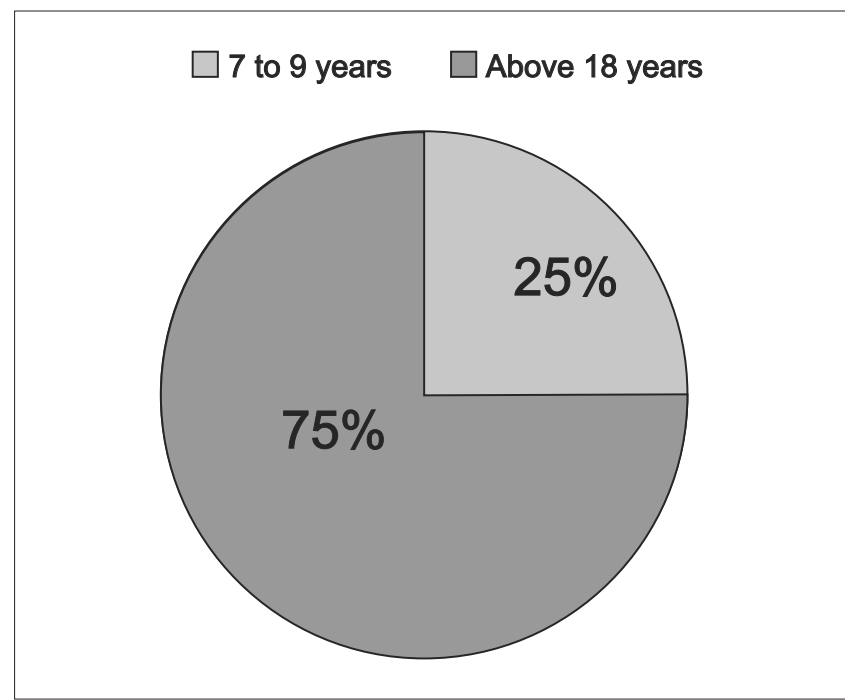

Image 4. Age of post-lingual patients at the time of surgery.

with the association for speech therapy twice a week and $20 \%(n=3)$ once during the week.

Time of use of cochlear implants

$53 \%(\mathrm{n}=8)$ to have 01 years of use of the device, $40 \%(n=6)$ make use of the implant for 2 to 3 years, and $7 \%(n=1)$ benefits from the system for over 3 years. (Image 6).

The above data show that the incidence of ototoxicity is more common in male patients $(n=5)$, whereas meningitis appeared more prevalent in females $(n=3)$. The other root causes were isolated cytomegalovirus ( $\mathrm{n}=$ $1)$, genetic factors $(n=1)$, auditory nerve damage $(n=1)$, traumatic brain injury $(n=1)$, and 1 undiagnosed case ( $n$ $=1$ ). 


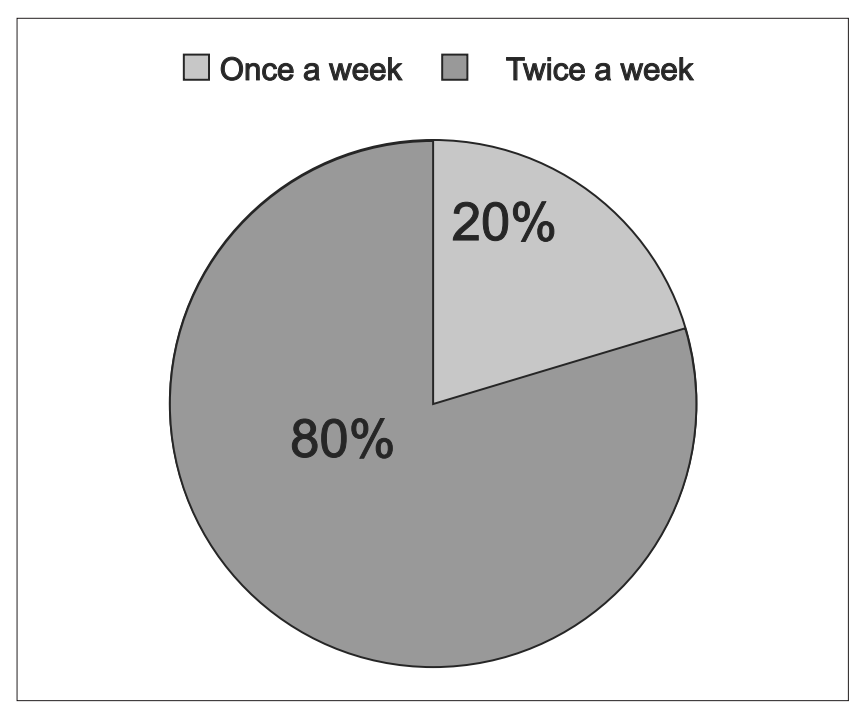

Image 5. Frequency of speech therapy.

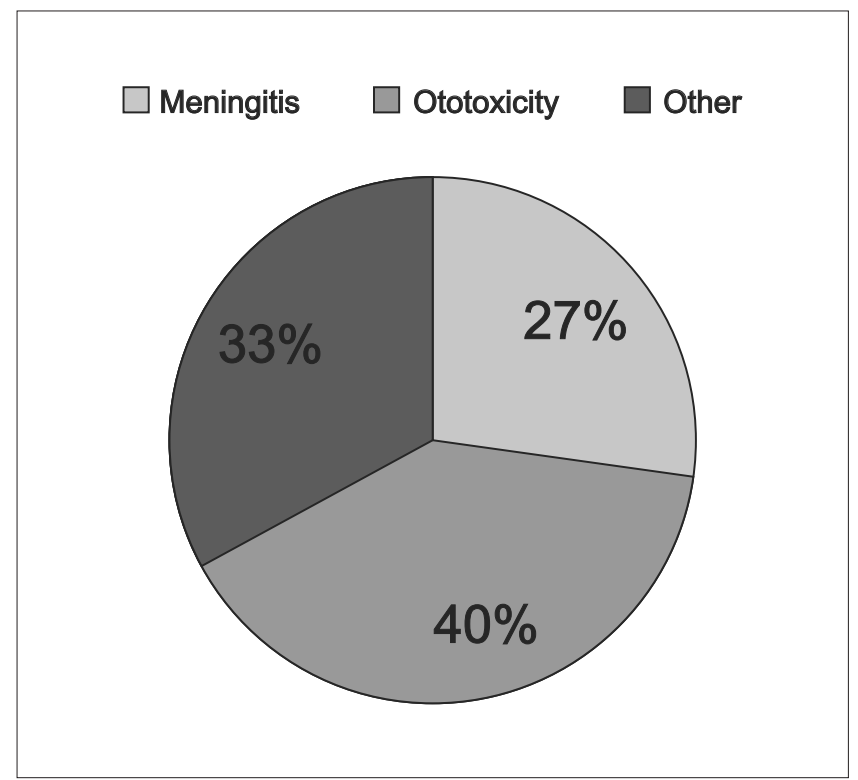

Image 7. Main etiological agents found in the studied population.

\section{General distribution of subjects according to the etiologic agents.}

The agent that causes deafness ototoxicity highest incidence was $40 \%$ of cases $(n=6)$, coupled with the fact that all respondents for that item were infants with a history of prematurity, low birth weight, and submission to treatment in neonatal NICU. The second-most relevant data with meningitis was $27 \%(\mathrm{n}=4)$. It is important to

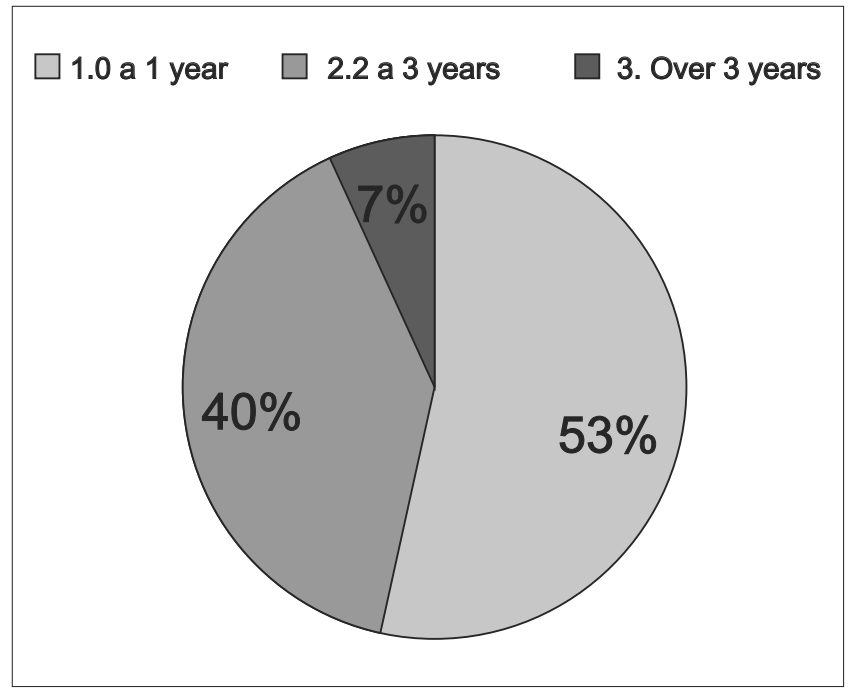

Image 6. Distribution of subjects according to duration of implant use.

Bilateral sensorineural hearing loss severe deep

Severe bilateral sensorineural hearing loss

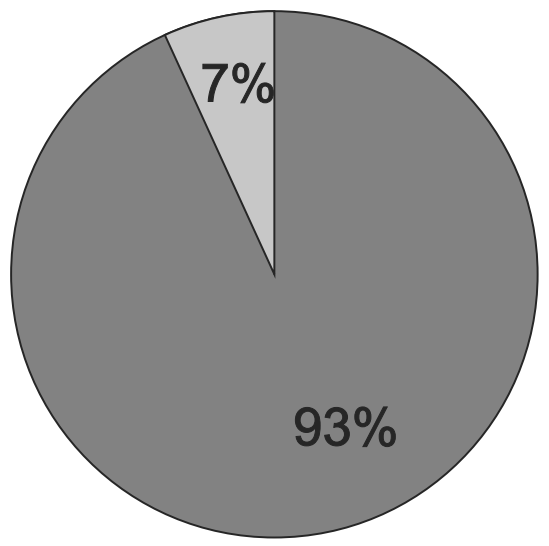

Image 8. Distribution of subjects by degree and type of hearing loss.

report that we find other etiologies isolated whose percentage was 33\% ( $n=5)$, among which we quote: cytomegalovirus, head trauma, congenital deafness, damage to the auditory nerve and one undiagnosed case (Image 7).

${ }^{1}$ Associated with prematurity and low birth weight. Newborns undergoing treatment in the NICU. 
Table 2. Distribution of subjects according to the etiology and sex.

\begin{tabular}{lccc}
\hline Etiology & Male & Female & Total \\
& $\mathrm{N}$ & $\mathrm{N}$ & \\
\hline 1. Congenital Rubella & 00 & 00 & 00 \\
2. Meningitis & 01 & 03 & 04 \\
3. Ototoxicity' & 05 & 01 & 06 \\
4. Cytomegalovirus & 00 & 01 & 01 \\
5. Geneticfactors & 01 & 00 & 01 \\
6. Lesionsinthe auditory nerve & 00 & 01 & 01 \\
7. Traumatic brain injury & 00 & 01 & 01 \\
8. Undiagnosed & 01 & 00 & 01 \\
\hline
\end{tabular}

\section{DISCUSSION}

The findings showed that $80 \%$ of the individuals within the criteria of holding speech therapy in his home town.

Lima, Marba, and Santos (2006, p. 115, emphasis added) found significant results in people "weighing less than $1000 \mathrm{~g}$, the presence of genetic syndrome, [...] the occurrence of meningitis, use of ototoxic medication for more Meningitis arises 27\% $(n=4)$. According Lichtig and Carvalho (1997, p. 245) and bacterial meningitis is responsible for $6-40 \%$ of acquired sensorineural hearing impairments that occur in school-age population." A study corroborates the findings of the research. According to Santos (2005) in Amazonas State, there were 640 cases and 104 deaths from 1998 to 2002 (data provided by the Health Department of the State of Amazonas SUSAM), and in Manaus; in the same period, 532 cases were confirmed and 74 deaths of meningococcal disease, according to data from the Municipal Health authority.

In screening patients registered in the Central Brazilian Cochlear Implants registry for surgery, among the causes examined, it was found that rubella, followed by meningitis, is the most frequently reported etiology. Such research points to the high incidence of these 2 diseases still present in the population with some type of hearing loss. (FAIR, 2010)

There were 3,818 reported cases of rubella with suspected pregnancy and risk of silent congenital rubella syndrome identified through the records of the Epidemiological Surveillance System of Manaus in the period 1998 to 2002. Of these, 103 cases (80.6\%) underwent tests being confirmed. (Mota, 2004). Rubéola was considered as likely to be confirmed in this group; however, we did not find a single individual with hearing loss, cochlear implant user who submit the etiological cause $(n=0)$. This fact is justified compared to the study in Manaus, because according to Mota (2004) avigilância, the Rubella Surveillance System in Manaus could only develop prevention and control when double viral vaccine (measles/rubella) was introduced in 2000, and MMR in 2003, during routine Public Health Unit Surveillance System for the City of Manaus, with the knowledge of this information, developed with state support, activities to structure the care of pregnant women positive for rubella as well as negative pregnant women in maternity wards in Manaus. These discussion regarding the policies adopted in the city of Manaus to the prevention of infectious diseases and, consequently, to minimize its effects on hearing.

\section{CONCLUSION}

The results indicate that despite the reduced number of cochlear implant users in Manaus, patients meet the criteria required by cochlear implant centers in Brazil, also mentioned by the literature. The determinants to characterize the profile of these patients and the type and degree of hearing loss, etiology causes of deafness, age at surgery, use of individual hearing aids before implantation, duration of use of the device, the process of language acquisition and to check whether the patient had access to habilitation/rehabilitation hearing in the city of origin, were crucial to the profile of the population studied.

We found that most of the hearing loss was due to ototoxicity associated with prematurity of newborns undergoing treatment in the NICU, and patients were predominantly pre-lingual (73\%). Regarding the degree and type of hearing loss, 93\% of respondents have audiological reports indicating profound bilateral sensorineural hearing loss, and $7 \%$ have severe bilateral sensorineural hearing loss.

As the therapeutic process, all patients have access to speech therapy, with the caveat that are supported largely by the association, thus fulfilling one of the requirements required for successful habilitation/rehabilitation of the patient implanted at the time of selection implantation, but with great difficulty. 


\section{REFERENCES}

1. Amantini RCB, Bevilacqua MC, Costa OA. Considerações sobre o implante coclear em crianças. In: Bevilacqua MC, Moret ALM (Orgs.) Deficiência Auditiva: conversando com familiares e profissionais de saúde. São José dos Campos: Pulso, 2005.

2. Bevilacqua MC, Moret AL. Implante Coclear em Crianças. In: LOPES FILHO, O.C. Tratado de Fonoaudiologia. São Paulo, Roca, 1997.

3. Bevilacqua MC et al. Implantes cocleares em crianças portadoras de deficiência auditiva decorrente de meningite. Rev. Bras. Otorrinolaringol. 2003;69(6):760764 .

4. Brasil. Ministério da Saúde. Manual de vigilância epidemiológica das doenças exantemáticas. Brasília, DF: FNS, 2003.

5. Brasil. Ministério da Saúde. Portaria n $\square 1278$, de 20 de outubro de 1999. Dispõe sobre a necessidade de estabelecer critérios de indicação e realização de implante coclear. Disponível em: <http://www.portal.saude.gov/ portal/sas/sapd/por 22689.shtm. >. Acesso em: 06 jun. 2010.

6. Costa Filho OA. et al. Implante coclear em adultos. In: Campos CAH, Costa HOO. Tratado de Otorrinolaringologia. São Paulo: Roca, 2002. p. 278289.

7. Costa Filho OA, Bevilacqua MC, Moreti ALM. Critérios de seleção de crianças candidatas ao implante coclear do Hospital de Pesquisa e Reabilitação de Lesões Lábio Palatais - USP. Rev. Bras. Otorrinolaringologia. 1996;62(4):306-313.

8. Jakubovicz R. Atraso de Linguagem: diagnóstico pela média dos valores da frase. São Paulo: Revinter, 2002.

9. Jornada AL. Comparação das alterações auditivas em recém-nascidos da UTI neonatal expostos e não expostos a antibióticos, por meio do teste de emissões otoacústicas. 2009.73f. Dissertação (Mestrado em Pediatria). PUCRS, Porto Alegra, 2009.

10. Kozlowski L. Implantes Cocleares. São Paulo: PróFono, 2000.

11. Kumar V, Abbas A, Fausto N. Patologia: bases patológicas das doenças. 7. ed. Rio de Janeiro: Elsevier, 2005.
12. Leal AF. Triagem de pacientes para implantes cocleares através de questionário online: Perfil do grupo de pacientes pré e peri-linguais não convocados. Arq. Otorrinolaringol. 2010;14(2):184-191.

13. Lichtig I, Carvalho RMM. Audição: Abordagens Atuais. Carapicuíba, SP: Pró-Fono, 1997.

14. Lima GML, Marba STM, Santos MFC. - Triagem auditiva em recém-nascidos internados em UTI neonatal. J. Pediatr. 2006;82(2):100-104.

15. Lopes Filho OC. Tratado de Fonoaudiologia. São Paulo: Roca, 1997.

16. Moret ALM. Princípios Básicos da Habilitação da criança Deficiente auditiva com Implante Coclear. In: Bevilacqua MC, Moret ALM, (Orgs.) Deficiência Auditiva: conversando com familiares e profissionais de saúde. São José dos Campos: Pulso, 2005.

17. Mota MFM. Avaliação do Sistema de Vigilância Epidemiológica de Manaus: Comportamento da Rubéola, 1998 a 2002. 2004. 68f. Dissertação (Mestrado em Doenças Tropicais e Infecciosas). UEA/FMTAM, Manaus, 2004.

18. Myamoto RT et al. Language development in deaf infants following cochlear implantantion. In: Pinto ESM. Análise dos procedimentos de seleção de crianças para o implante coclear. (Tese de Doutorado) Campinas, São Paulo: 2007. p. 42-50.

19. Pinto ESM. Análise dos procedimentos de seleção de crianças para o implante coclear. (Tese de Doutorado) Campinas, São Paulo: 2007. p. 42-50.

20. Porto PRC. Avaliação de resultados de implante coclear em pacientes deficientes auditivos secundário à meningite. (Dissertação de mestrado) Campinas, SP: [s.n], 2002.

21. Prestes MLM. A pesquisa e a construção do conhecimento científico: do planejamento aos textos, da escola à academia. São Paulo: Respel, 2007.

22. Ramalho KA. Análise retrospectiva das sequelas de meningite em crianças de uma unidade hospitalar especializada. 2008. 102f. Dissertação (Mestrado) Pontifícia Universidade Católica de São Paulo, São Paulo, 2008.

23. Russo ICP, Momensohn-Santos TM. (Orgs.) Prática da Audiologia Clínica. 5. ed. São Paulo: Cortez Editora, 2005. 
24. Sant'Anna SBG. O implante coclear e a atuação fonoaudiológica. In: Silva PB, David RHF. (Orgs.) Cadernos da Fonoaudiálogo: Audiologia. São Paulo: Lovise, 2008.

25. Santos ML. Doença meningocócica: situação epidemiológica no Município de Manaus, Amazonas, Brasil, 1998/2002. Cad. Saúde Pública 2005;21(6).
26. Segre CAM. Prevalência de perda auditiva em recémnascidos de muito baixo peso. J. Pediatr. 2003;79(2):103104. 